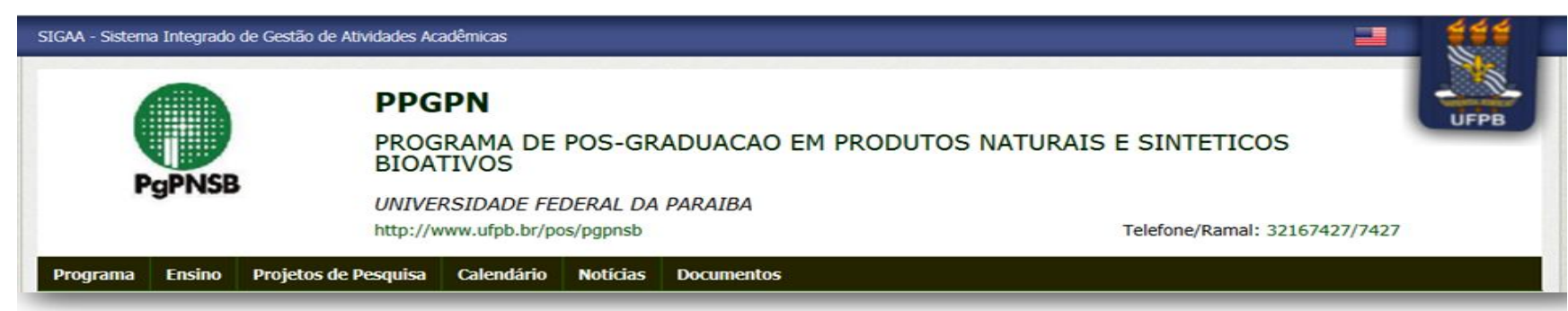

\title{
Sciforum
}

MOL2NET

\section{The use of the Ginkgo Biloba plant and its interaction with other drugs}

\author{
Raiza Santos de Góis ${ }^{1, *}$, Wandemberg Farias de Albuquerque Neto ${ }^{2}$, Cláudia Kowalesky Silva \\ 3, Lucas Miguel Lima do Amaral ${ }^{4}$,Vanessa de Melo Cavalcanti Dantas ${ }^{5}$,Daniela Bomfim de \\ Barros ${ }^{6}$,Lúcio Roberto Cançado Castellano ${ }^{7}$ andPaulo Rogério Ferreti Bonan ${ }^{8}$ \\ 1*FPB - Faculdade Internacional da Paraíba, João Pessoa - PB/Brasil; E-Mail: raizagois@ outlook.com; \\ raizagois@ @otmail.com; Tel.: +55-083-99656-2617; \\ ${ }^{2}$ FPB - Faculdade Internacional da Paraíba, João Pessoa - PB/Brasil; \\ ${ }^{3}$ FPB - Faculdade Internacional da Paraíba, João Pessoa - PB/Brasil; \\ ${ }^{4}$ FPB - Faculdade Internacional da Paraíba, João Pessoa - PB/Brasil; \\ ${ }^{5}$ FPB - Faculdade Internacional da Paraíba, João Pessoa - PB/Brasil; \\ ${ }^{6}$ FPB - Faculdade Internacional da Paraíba, João Pessoa - PB/Brasil; \\ ${ }^{7}$ UFPB - Universidade Federal da Paraíba, João Pessoa - PB/Brasil; \\ ${ }^{8}$ UFPB - Universidade Federal da Paraíba, João Pessoa - PB/Brasil.
}

Received: / Accepted: / Published:

\begin{abstract}
:
The use of phytotherapic medicines is widely used, mainly as a complementary medication for patients with chronic diseases. Studies on Ginkgo biloba extract shows relevant pharmacological activities to the treatment on Alzheimer's disease, memory deficit, depression, and promising effects on cognitive functions in clinical studies. As a result, research about the interaction of Ginkgo biloba with other medicinal products has been increasing, as this may interfere with the pharmacokinetics and pharmacodynamics of several drugs, and may have serious consequences for the patient. Objective: The objective of this study is to show interactions of Ginkgo biloba with other drugs and their influence on their physiological action. Methodology: This abstract is a review that aims to collect and combine information about the interactions of Ginkgo biloba with other drugs, using bibliographic data. Results and Discussion: Studies show that administration of Ginkgo biloba combined with anticonvulsants tends to decrease the action of these drugs. Combined with antidepressants (as monoamine oxidase inhibitors) it intensifies the pharmacological action of the drug and also the side effect, such as headache, tremors and maniac outbreak. When using Ginkgo biloba with Sertraline it is reported that it may cause increased heart rate, excessive sweating, hyperthermia, muscle stiffness and
\end{abstract}


agitation. The use of Ginkgo biloba with Omeprazole lower the plasma concentration of this drug, and consequently, its therapeutic effect. Conclusion: Proper use of some herbal supplements is perfectly safe and can cause benefits, but their indiscriminate or excessive use can be dangerous. With all of the above being said, the concomitant use of phytotherapic medicines such as Ginkgo biloba based combined with other drugs should be appropriately monitored.

Keywords: Ginkgo biloba; Pharmacological Interaction; Herbal Remedy.

Mol2Net YouTube channel: http://bit.do/mol2net-tube

YouTube link: please,paste here the link to your personal YouTube video, if any.

\section{Introduction}

Ginkgo biloba $(\mathrm{GB})$ is a tree native to China, Korea and Japan, an ancient plant that was considered by Charles Darwin to be a "living fossil" (FILHO; FAKOURY; FERRY, 2009). It is one of the best-selling medicinal herbs in the United States and Europe, used in the treatment of central nervous system and cardiovascular diseases (SILVA et al., 2010).

Latter has been shown to be effective in patients with mild Alzheimer's disease, since it promotes vasodilation and lowers blood viscosity and protects neurons against oxidative stress. These justifications reiterate the success of this medication when administered at the beginning of the pathology (FORLENZA, 2005; NICOLETTI, et al. 2007).

\section{Results and Discussion}

Concerning the use of the Gingko biloba extract and other medicines, the use of $80 \mathrm{mg}$ of this plant twice daily with Trazodone $20 \mathrm{mg}$ twice a day too may cause coma on the third day. To reverse the case, intravenous injection of Flumazenil should be used. This happens because the flavonoids present in GB may increase gabaergic activity, and studies have shown that it can interfere with the action of oral and antiplatelet anticoagulants and with drugs metabolized by the P450-CYP3A4 system (DEFEUDIS, 1998; ALEXANDRE; BAGATANI; SIMÕES, 2008; SILVA et al.,

\section{Materials and Methods}

A search was made to collect information about the possible interactions of Ginkgo biloba with several drugs, without date and language restrictions. We used the databases PUBMED,

SCIELO and NCBI, with a survey of clinical studies of articles using as descriptors: "Ginkgo biloba", "Pharmacological Interaction", "Phytotherapics".

2010). According to Silva et al. (2010), when administered the GB associated with thiazide diuretics (hydrochlorothiazide) can cause, after a week, the increase of the patient's blood pressure.

Nicoletti et al. (2007) reinforce that preliminary studies demonstrate that GB can affect insulin levels, which demands additional care for the users of these drugs. It has also been observed that high doses of Ginkgo biloba may raise blood pressure when administered with foods that have high levels of protein or in preserves that have tyramine (FILHO; FAKOURY; FERRY, 2009). 
MOL2NET, 2016, 2(14), pages 1- $\mathrm{x}$

http://sciforum.net/conference/mol2net-02/wrsamc

\section{Conclusions}

The facts presented are insufficient for the wisdom of the harm or benefits of Ginkgo biloba, since the number of case reports is still small since there is no common sense among physicians to relate the adverse effects of the drugs to plants or herbal medicines. Further research is needed to understand the effects and mechanism of action of Ginkgo biloba.

\section{Acknowledgments}

I thank the research group LACEC and my advisors Vanessa Dantas and Daniela Bomfim for the academic growth and for all shared scientific knowledge.

\section{Conflicts of Interest}

The authors declare no conflict of interest.

\section{References and Notes}

1. Alexandre, R. F.; Bagatini, F., Interactions between drugs and ginkgo or ginseng herbal medicines, Rev Bras Farmacogn, 2008, 18, 117-126, http://dx.doi.org/10.1590/S0102695X2008000100021 Available online: http://www.scielo.br/scielo.php?script=sci_arttext\&pid=S0102-695X2008000100021 (accessed on 2sept2018).

2. Barnes, P.M.; Powell, G.E., Complementary and alternative medicine use among adults: United States, 2002. Adv Data 2004, 27, 1-19. Available online: https://www.ncbi.nlm.nih.gov/pubmed/15188733 (accessed on 2sep2018).

3. Filho, A.C.; Fakoury, M.K., Ginkgo biloba and memory - systematic review. Rev. bras. geriatr. gerontol 2009, 13, 145-152, http://dx.doi.org/10.1590/S1809-98232010000100015 Available online: http://www.scielo.br/pdf/rbgg/v13n1/a15v13n1.pdf (accessed on 2sept2018).

4. Forlenza, O.V. Pharmacological treatment of Alzheimer's disease. 2005, http://dx.doi.org/10.1590/S0101-60832005000300006 Available online: http://www.scielo.br/scielo.php?script=sci_arttext\&pid=S0101-60832005000300006 (accessed on 2sep2018).

5. Nicoletti, M. A.; Júnior, M. A. O., Principais interações no uso e medicamentos fitoterápicos, Infarma 2007, 19, 33-36.

6. Silva, T. F. O.; Marcelino, C. E., Utilizações e Interações Medicamentosas de Produtos Contendo o Ginkgo Biloba, Colloquium Vitae, 2010, 2, 54-61.

7. Venturini; Engroff, P.; Interações entre antiparasitários e alimentos. Revista de Ciências Farmacêuticas Básica e Aplicada, 2014, 3, 17-23.

\section{Notes:}

MDPI do not released one specific template for Sciforum conference. Consequentyl, this is not official templatereleased by MDPI.In principle, the papers may be presented without specific format.

However, the chairperson and the secretariat of the conference decided to create this template to give homogeneity to Mol2Net works. As is, this template should be used only for Mol2Net conference. Please, do not use this template for MDPI journals. Please, delete these notes before saving your final version. Type of the Paper (Proceeding, Letter, Expert Opinion, Communication, etc.). MDPI generates doi upon author request.

YouTube link:this option is only for those authors with welcome videos and/or oral presentations, plenary conferences uploaded to Mol2Net YouTube site.

Reference list:We recommend the use of reference management software to prepare the references list (e.g., Endnote, http://endnote.com/styles/MDPI.ens).

(C) 2015 by the authors; licensee MDPI, Basel, Switzerland. This article is an open access article distributed under the terms and conditions defined by MDPI AG, the publisher of the Sciforum.net platform. Sciforum papers authors the copyright to their scholarly works. Hence, by submitting a paper to this conference, you retain the copyright, but you grant MDPI AG the non-exclusive and unrevocable license right to publish this paper online on the Sciforum.net platform. This means you can easily submit your paper to any scientific journal at a later stage and transfer the copyright to its publisher (if required by that publisher). (http://sciforum.net/about). 